\title{
To What Extent Do Protected Areas Determine the Conservation of Native Flora? A Case Study in the Sudanian Zone of Burkina Faso
}

\author{
Lassina Traoré, Amadé Ouédraogo, and Adjima Thiombiano \\ Laboratory of Plant Biology and Ecology, University of Ouagadougou, 03 BP 7021, Ouagadougou 03, Burkina Faso \\ Correspondence should be addressed to Lassina Traoré, ltraorej@gmail.com
}

Received 24 August 2012; Accepted 13 September 2012

Academic Editors: A. Culham and S. Jansen

Copyright () 2012 Lassina Traoré et al. This is an open access article distributed under the Creative Commons Attribution License, which permits unrestricted use, distribution, and reproduction in any medium, provided the original work is properly cited.

\begin{abstract}
Natural vegetation contributes significantly to the daily needs of local people especially in the developing countries. This exerts a high pressure on freely accessible natural savannas and jeopardizes the conservation of protected areas. In Burkina Faso, conservation measures, such as the creation of protected forests, have been taken to safeguard the remaining indigenous vegetation. However, little is known about the effectiveness of these protected areas in conserving biodiversity. This study compared the diversity and structural characteristics of the vegetation communities in protected and unprotected areas in the Sudanian zone of Burkina Faso. A total of 208 species representing 41 families and 145 genera were found. Significant differences were found between the species richness in the north Sudanian sector for tree savannas and in the south Sudanian sector for the shrub savannas, tree savannas, savanna woodlands, and the woodlands of land use types. All tree size-class distributions in each vegetation type formed a reverse J-shaped curve, indicating vegetation dominated by juvenile individuals. Similarity in tree species composition between management regimes was found to be low, which reflects differences in habitat conditions, disturbance, and topography. Urgent measures are needed to ensure effective and efficient management and conservation of biodiversity in the protected areas of Burkina Faso.
\end{abstract}

\section{Introduction}

In West Africa, the degradation of savanna woodlands due to agricultural expansion, overgrazing, bush fire and wood cutting is a serious environmental concern $[1,2]$. The current mosaic of these savanna-woodland ecosystems is the result of combined climate pejoration and human pressure impacts. The overexploitation of the parklands is reported as a major cause of the degradation of vegetation cover and loss of biodiversity [3]. In general, this phenomenon is observed in many areas of West Africa [4-6] and particularly in Burkina Faso where the dynamics of land occupation for agriculture is extensive. In this way the natural vegetation declines and the human pressure on the protected areas increases. Western Burkina Faso is the principal area of the cotton production in the country [7]. This agricultural basin is regarded as a space with high economic potentialities and consequently attracts more and more people from other parts of the country. The increasing demand of agriculture lands is to the detriment of the ancient traditional fallow practices which favor the conservation and restoration of parklands [8].

In the 1930s, a large part of the Sudanian zone of West Africa was delimited and protected by the colonial administration to create wildlife sanctuaries and prevent the expansion of shifting cultivation [9]. Following political independence, these forests and woodland reserves were conserved through the status of state forests for wood production, ecotourism, and biodiversity conservation [9]. In Burkina Faso, natural land reserves represent $26 \%$ of the country's total area $[9,10]$.

A consensus emerges with regard to the need for preserving the protected areas. However, a better conservation management depends initially on the understanding of specific factors and thorough causes which are responsible for the degradation process. The aim of this study was to assess the impact of protected areas on the woody plants 


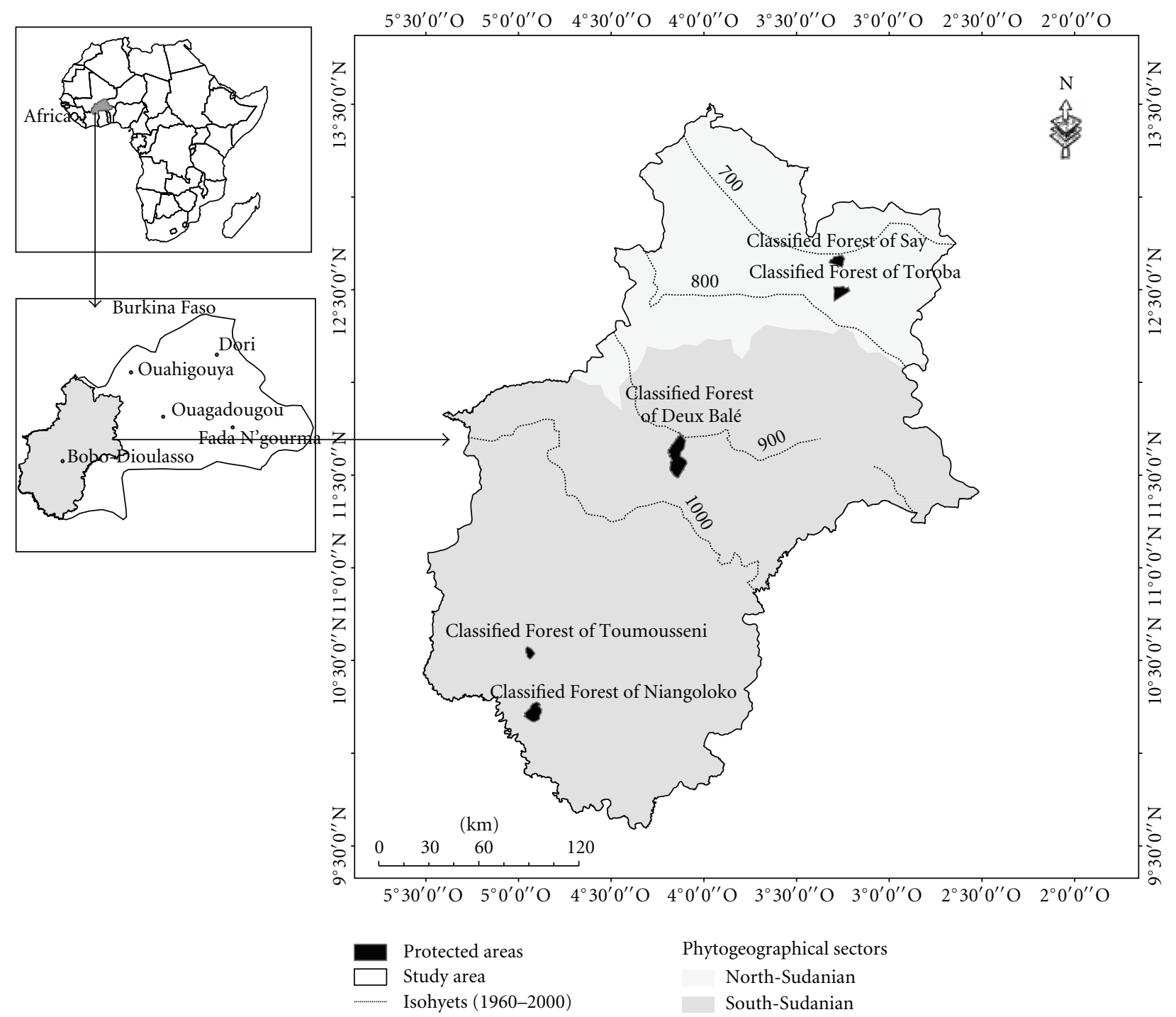

FIgUre 1: The location of the study sites within the sudanian zone, western Burkina Faso.

communities in the different vegetation types between two land use regimes in Western Burkina Faso. We hypothesize that the diversity and structural characteristics of woody vegetation would be enhanced within protected areas. The results of this study will provide information that could help to conciliate land use regimes with sustainable management and conservation of woody species communities.

\section{Materials and Methods}

2.1. Study Area. This paper was carried out in Western Burkina Faso across two phytogeographical sectors, the north-Sudanian (NS) and the south-Sudanian (SS) sectors [11]; this area is situated between $9^{\circ} 30^{\prime}-13^{\circ} 30^{\prime} \mathrm{N}$ and $5^{\circ} 30^{\prime}-$ $2^{\circ} 30^{\prime} \mathrm{W}$ (Figure 1). The rainy season lasts from May to October and the annual rainfall range is $700-800 \mathrm{~m}$ and 900 $1000 \mathrm{~m}$ in the north and south sudanian sectors, respectively. The mean annual temperature ranges from 15 to $40.8^{\circ} \mathrm{C}$ and 17 to $37.9^{\circ} \mathrm{C}$, in the NS and the SS, respectively. The dominant soils are ferralsols and lixisols ranged from poorly to completely leached ones $[1,12]$. Specific common woody species are Acacia seyal Del., Combretum micranthum G. Don, and Guiera senegalensis J. F. Gmel. in the northSudanian zone and Acacia sieberiana DC., Burkea africana Hook. F, Daniellia oliveri (R.) Hutch. and Dalz. C, and Isoberlinia doka Craib. and Stapf. for the south-Sudanian sector.

In this study, protected areas (PAs) are defined as clearly delimited areas of natural vegetation that have been officially classified - with appropriate legal status-by public authorities with the aim of ensuring protection of natural resources as well as ecosystem functions and services. Data were collected in five PAs across the study area. All the five PAs have a status of classified forests: classified forests of Say and "Toroba" (Dédougou) were sampled in the north-Sudanian sector, and classified forests of "deux Balé" (Boromo), of "Toumousséni" (Banfora) and "Niangoloko" in the south Sudanian sector. Say and Toroba state forests 
were classified in 1937 and 1938, respectively. They cover 5400 ha and 2700 ha, respectively. Balé, Niangoloko, and Toumouséni were classified in 1937, 1936, and 1954 and cover 57000 ha, 124500 ha, and 2500 ha, respectively. Toroba, Balé, Toumousséni, and Niangoloko are managed by the State Forest Department Services. Say is under a private management by a concessionaire [13]. Illegal logging, grazing, and harvesting of nonwoody forest products are frequent in all these protected areas. Unprotected areas (UAs) in this study are fallows, freely accessible natural savannas, and unsuitable lands for agriculture but used for pasture (e.g., rocky lands). Unprotected areas are strongly affected by various anthropogenic activities, for example, extensive livestock grazing, bush fires, and various harvestings of timber and nontimber forest products including wood, leaves, bark, flowers, and fruits.

2.2. Data Collection. The considered plant communities are shrub savannas, tree savannas, woodland savannas, woodland and gallery forests as defined by Aubreville [14]. The inventory design followed a random sampling scheme and was applied systematically in and outside selected protected areas across the north and south Sudanian zones. Sampling units were $1000 \mathrm{~m}^{2}(20 \mathrm{~m} \times 50 \mathrm{~m})$ size plots at the rate of $10-15$ plots per vegetation type and per phytogeographical sector. Data collection consisted in recording and identifying all woody species and measuring their diameter at breast height (DBH). A measuring tape was used to measure girth at breast height $(\mathrm{GBH}$, at height $1.3 \mathrm{~m})$, which was then converted to the following diameter at breast height (DBH) using the formula: $\mathrm{DBH}=\mathrm{GHB} / \pi$. A total of 256 plots were reached and distributed as follows: NS-PAs: 51, NS-UAs: 52, SS-PAs: 82, and SS-UAs: 71.

2.3. Data Analysis. Mean population density was calculated for each vegetation community in protected areas (PAs) and in unprotected areas (UAs). $t$-tests were used to compare mean population density and basal areas between the two types of management regimes. Results were considered significant at $P<0.05$.

2.3.1. Species Richness and Diversity. For each vegetation community, we calculate the following ecological parameters which are widely used indices to measure biological diversity [15]:

(i) Shannon's diversity index $\left(H^{\prime}\right)$ :

$$
H^{\prime}=-\sum_{i=1}^{s} p_{i} \ln p_{i}
$$

where $s$ is the total number of species in the community (richness) and $p_{i}$ is the relative abundance of the $i$ th species in a plot.

(ii) Simpsons' Index $(D)$ :

$$
D=\sum_{i=1}^{s} \frac{N i(N i-1)}{N(N-1)},
$$

where $N i$ is the number of individual of the $i$ th species and $N$ is the total number of species in vegetation types. $D=0$ indicates high diversity, and 1 indicates low diversity. In order to obtain "more intuitive" values, $1-D$ was calculated, the maximum of diversity being represented by value 1 , and the minimum of diversity by value 0 .

(iii) Hill's Diversity Index:

$$
\text { Hill }=\frac{(1 / D)}{e^{H^{\prime}}},
$$

where $1 / D$ represents Simpson's index and $e^{H^{\prime}}$ is Shannon's exponential index. Hill's index of diversity makes it possible to obtain a more precise appreciation of observed diversity. In order to facilitate interpretation, it is then possible to use the index 1-Hill; maximum diversity will be represented by value 1 and minimal diversity by value 0 . Hill's index seems most relevant as so far it integrates the two other indices (Shannon and Simpson) and allows comparisons between vegetation communities.

To evaluate $\beta$-diversity (similarity between vegetation communities), Jaccard's similarity index and Horns' modification of Morisita's index were computed. Jaccard's coefficient of similarity was calculated based on presence/absence data of the species while Horn's modification of Morisita's index takes the species abundance into account. Both indices vary between 0 and 1: a value close to 1 indicates greater similarity between sites and hence low $\beta$-diversity [15].

2.3.2. Population Structure and Size-Class Distribution. For each plant community the following structural parameters were calculated.

(i) the tree density of the stands $(N)$, that is, the average number of trees per plot expressed in trees/ha

$$
N=\frac{n}{s},
$$

$n$ is the overall number of trees in the plot, and $s$ is the area of plot $(s=0.10$ ha).

(ii) the basal area of stands ( $\mathrm{G}$, in $\mathrm{m}^{2} / \mathrm{ha}$ ), that is, the sum of the cross-sectional area at $1.3 \mathrm{~m}$ above the ground level of all trees on a plot, expressed in $\mathrm{m}^{2} / \mathrm{ha}$ as follows:

$$
G=\pi x \frac{D_{i}^{2}}{4},
$$

$D_{\mathrm{i}}$ is the diameter of tree at $1.3 \mathrm{~m}$ above the ground level.

Mean population density was calculated for each species in protected areas (PAs) and in unprotected areas (UAs). $t$ tests were used to compare mean population density and basal areas between the two types of management regimes. Results were considered significant at $P<0.05$.

To establish the size-class distributions (SCDs), diameters of all trees $(\mathrm{dbh} \geq 5 \mathrm{~cm})$ were used to construct histograms with size classes of $5 \mathrm{~cm}$ interval. The observed shape was adjusted to the 3-parameter-Weibull theoretical distribution because of its flexibility [16]:

$$
f(x)=\frac{c}{b}\left[\frac{(x-a)}{b}\right]^{c-1} e^{-[x-a / b]^{c}},
$$




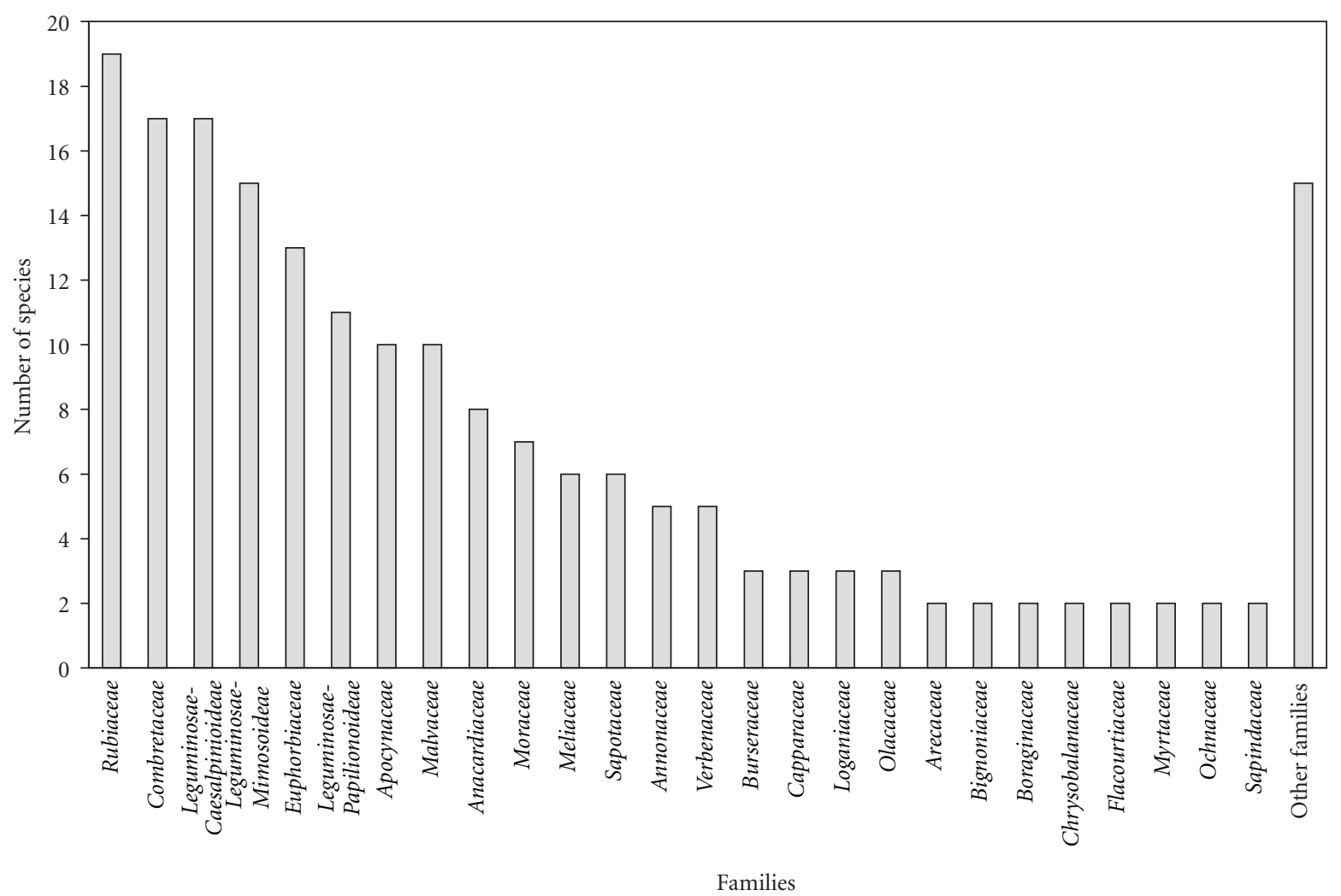

Figure 2: Plant's families.

where $x=$ tree diameter, $a=5 \mathrm{~cm}$, the threshold trees diameter structure, $b=$ scale parameter linked to the central value of diameters, and $c=$ shape parameter of the structure. For each community, tree diameter was used to estimate the parameters $b$ and $c$ based on the maximum likelihood method [17]. The Weibull distribution reveals a wide variety of shapes expressed by the shape parameter $c$ [18]. When $c<$ 1 the distribution has a reversed J shape; whilst when $c=1$ it is a negative exponential distribution. For values of $c>1$ the distribution is unimodal. If $1<c<3.6$ the distribution has a positive skew; when $c=3.6$ it is approximately normal and when $c>3.6$ the distribution has a negative skew. This adjustment covers diameter distributions that are strongly positively or negatively skewed as well as normally distributed $[19,20]$.

In each case the log-linear analysis [21] was performed in SAS [22] to test the adequacy of the observed structure to the Weibull distribution. The following model, described by Caswell [21], was used:

$$
\log \text { Frequency }=F+F_{\text {_Class }}+F_{\text {-adjustment }}+\varepsilon,
$$

where $F=$ mean frequency of the classes, $F_{-}$Class $=$nonrandom gap linked to the differences in frequency between classes, $F_{\text {-adjustment }}=$ nonrandomly gap linked to differences between observed and theoretical frequencies, and $\varepsilon=$ error of the model.

The hypothesis of adequacy between both distributions is accepted if the probability value of the test is higher than 0.05 .

\section{Results}

3.1. Species Richness and Woody Plant Community Structures. A total of 208 species, distributed within 145 genera and 41 families, were recorded in both phytogeographical zones. The Rubiaceae, Combretaceae, LeguminosaeCaesalpinioideae, and Leguminosae-Mimosoideae families showed the highest number of species in both management regimes (Figure 2).

In the north sudanian area, the $t$-test revealed that the mean specific richness differed significantly only in tree savannas between PAs and UAs $(P=0.006)$, being highest in the PAs (57 species) than in the UAs (19 species). Acacia dudgeoni, Acacia seyal, Boswellia dalzielii, Burkea africana, Detarium microcarpum, Combretum molle, Loeseneriella africana, Pseudocedrela kotschyi, and Xeroderris stuhlmannii were the exclusive species in the tree savannas of the PAs.

As far as the structural parameters of stands are considered, no significant difference was observed between land use types in all vegetation communities. The mean stem density and the mean basal area did not significantly increase from UAs to the PAs for all plant communities in both phytogeographical sectors (Table 3). The observed SCDs for all plant communities showed a reverse "J" shape; with a Weibull shape parameter smaller than or close to 1 ; this is an indication of a steeply descending monotonic distribution function (Figure 3(a)).

In the south sudanian zone, the mean values of specific richness showed significant differences between the two land 


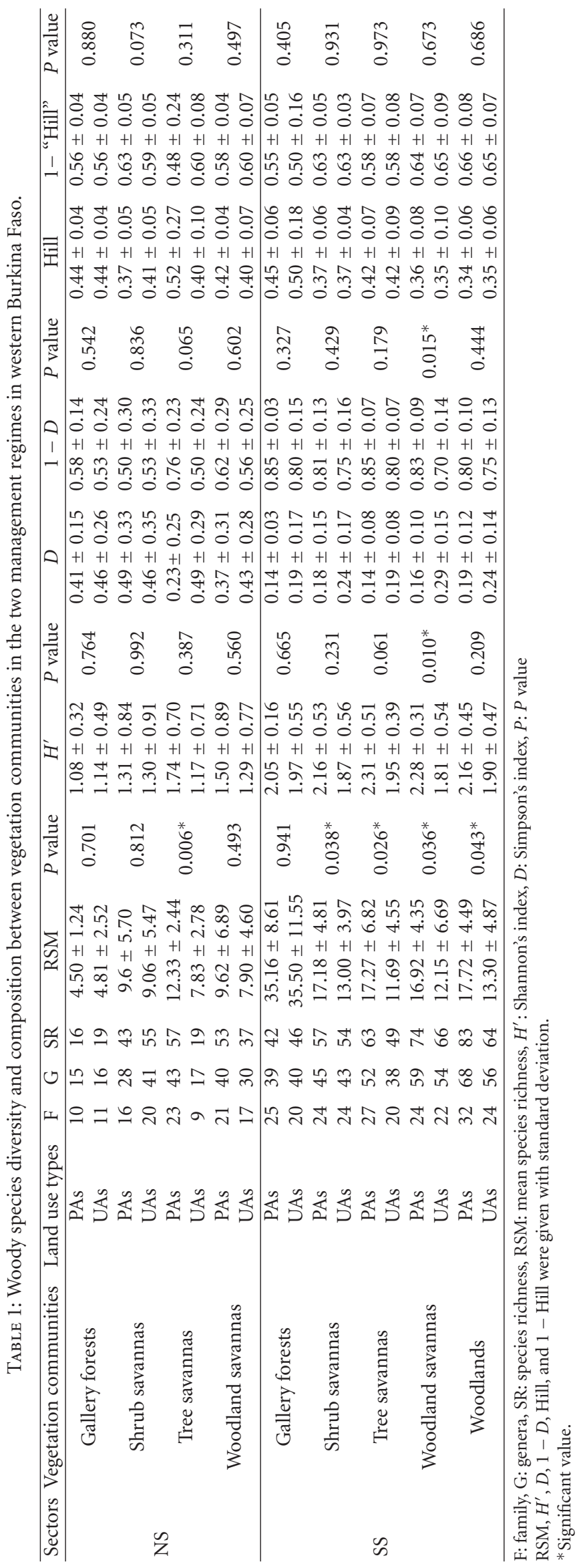



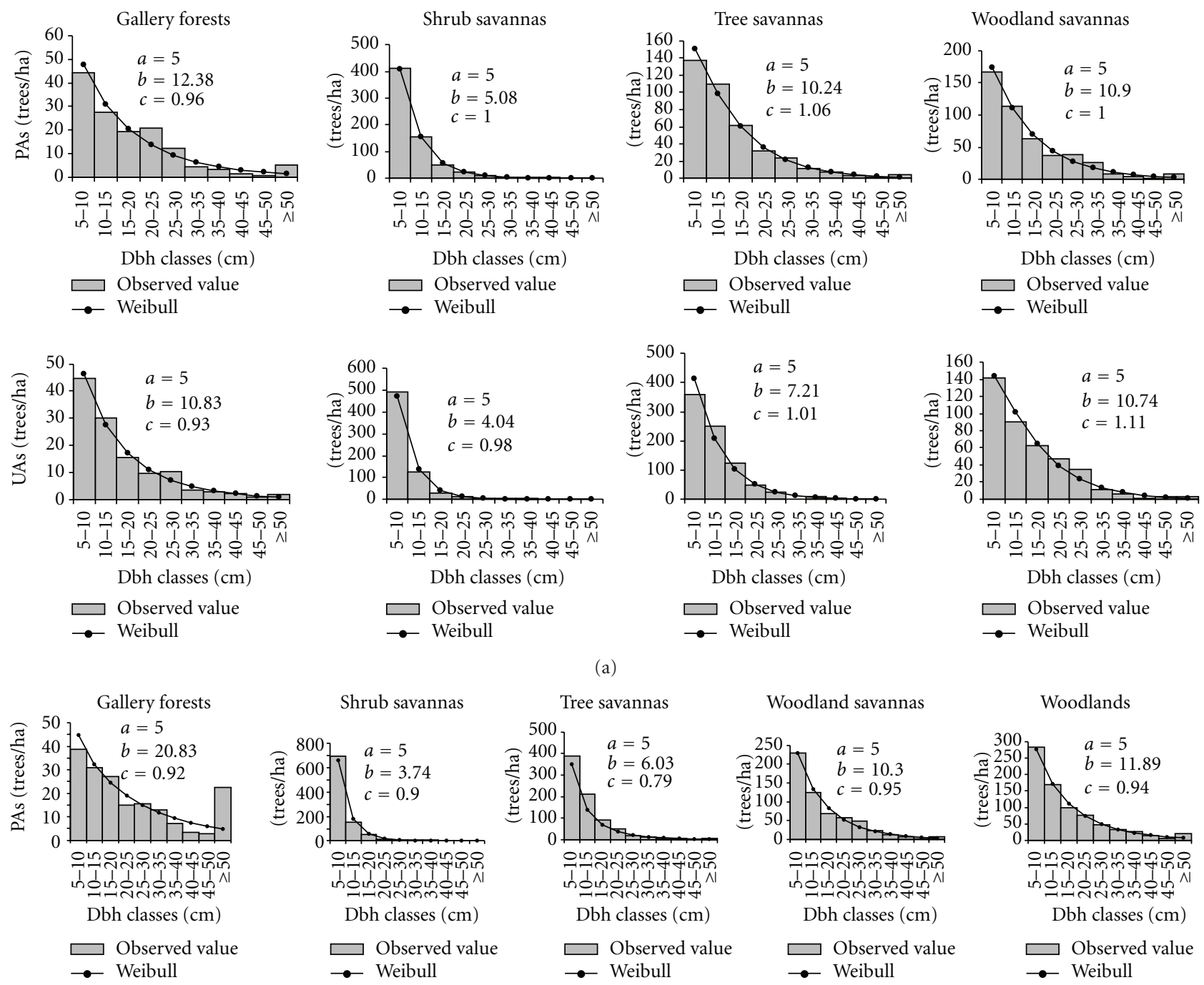

Woodland savannas
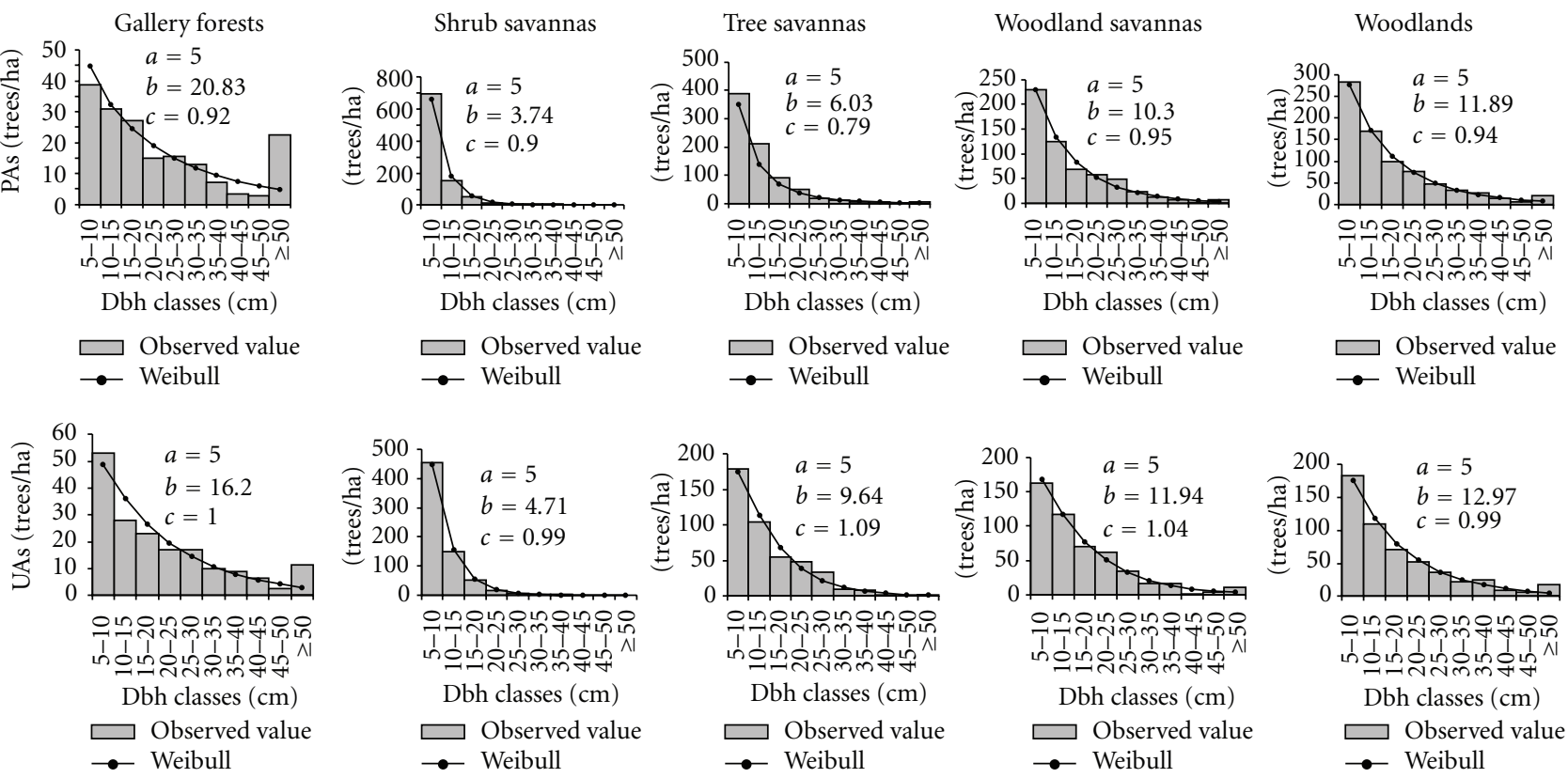

(b)

FIGURE 3: The size-class distribution (SCDs) of vegetation communities in protected areas (PAs) and unprotected areas (UAs): (a) for the north and (b) for the south Sudanian sectors of Burkina Faso. a, b and c are the three parameters of the Weibull theoretical distribution.

use types in the shrub savannas $(P=0.038)$, tree savannas $(P=0.026)$, savanna woodlands $(P=0.036)$, and woodlands $(P=0.043)$. For each vegetation community, species richness was highest in the PAs than in the UAs (Table 1). Ficus sur, Flacourtia flavescens, Monotes kerstingii, Syzygium guineense, and Xeroderris stuhlmannii in the shrub savannas; Malacantha alnifolia, Mimusops kummel, Monotes kerstingii,
Ekebergia senegalensis, Sericanthe chevalieri, and Syzygium guineense in the tree savannas; Ekebergia senegalensis, Erythrophleum africanum, Hexalobus monopetalus, Manilkara multinervis, Lannea barteri, and Swartzia madagascariensis in the savanna woodlands, and Capparis tomentosa, Carissa edulis, Cola cordifolia, Erythrophleum suaveolens, Lonchocarpus cyanescens, Syzygium guineense, and Mimusops kummel 
TABLE 2: Similarity in the species composition between vegetation communities in two management regimes in western Burkina Faso.

\begin{tabular}{|c|c|c|c|c|c|c|c|c|c|c|c|c|c|c|c|c|c|}
\hline \multirow[b]{3}{*}{ Indices } & \multicolumn{8}{|c|}{ North sudanian } & \multicolumn{9}{|c|}{ South sudanian } \\
\hline & \multicolumn{2}{|c|}{ Gf } & \multicolumn{2}{|c|}{ Shs } & \multicolumn{2}{|c|}{ Ts } & \multicolumn{2}{|c|}{ Ws } & \multicolumn{2}{|c|}{ Gf } & \multicolumn{2}{|c|}{ Shs } & \multicolumn{2}{|c|}{ Ts } & \multicolumn{2}{|c|}{ Ws } & $\mathrm{W}$ \\
\hline & PAs & UAs & PAs & UAs & PAs & UAs & PAs & UAs & PAs & UAs & PAs & UAs & PAs & UAs & PAs & UAs & PAs \\
\hline Jaccard & \multicolumn{2}{|c|}{0.402} & \multicolumn{2}{|c|}{0.515} & \multicolumn{2}{|c|}{0.333} & \multicolumn{2}{|c|}{0.475} & \multicolumn{2}{|c|}{0.275} & \multicolumn{2}{|c|}{0.541} & \multicolumn{2}{|c|}{0.435} & \multicolumn{2}{|c|}{0.463} & 0.475 \\
\hline Morisita-Horn & \multicolumn{2}{|c|}{0.585} & \multicolumn{2}{|c|}{0.589} & \multicolumn{2}{|c|}{0.288} & \multicolumn{2}{|c|}{0.615} & \multicolumn{2}{|c|}{0.375} & \multicolumn{2}{|c|}{0.565} & \multicolumn{2}{|c|}{0.491} & \multicolumn{2}{|c|}{0.605} & 0.786 \\
\hline
\end{tabular}

PAs: protected areas, UAs: unprotected areas, and Gf: gallery forests; Shs: shrub savannas, Ts: tree savannas, Ws: woodland savannas, and W: woodlands. Jaccard's similarity index and Morisita's index were computed to evaluate the similarity between vegetation communities. Both indices vary between 0 and 1 : a value close to 1 indicates a greater similarity between sites and hence low $\beta$-diversity.

TABLE 3: Structural characteristics of woody plant communities according to phytogeographical sectors and land use types (PAs and UAs).

\begin{tabular}{|c|c|c|c|c|c|c|c|c|}
\hline Sectors & Vegetation communities & Land use types & $\begin{array}{c}\text { Mean stems density } \\
\left(\mathrm{N} \cdot \mathrm{ha}^{-1}\right)\end{array}$ & SE & $P$ value & $\begin{array}{c}\text { Mean basal areas } \\
\left(\mathrm{m}^{2} \mathrm{ha}^{-1}\right)\end{array}$ & SE & $P$ value \\
\hline \multirow{8}{*}{ NS } & \multirow{2}{*}{ Gallery forests } & PAs & 551.7 & 184.0 & \multirow{2}{*}{0.426} & 19.84 & 11.05 & \multirow{2}{*}{0.711} \\
\hline & & UAs & 485.5 & 207.5 & & 17.53 & 17.99 & \\
\hline & \multirow{2}{*}{ Shrub savannas } & PAs & 654.0 & 266.3 & \multirow{2}{*}{0.923} & 6.61 & 2.85 & \multirow{2}{*}{0.203} \\
\hline & & UAs & 666.9 & 360.7 & & 5.39 & 1.94 & \\
\hline & \multirow{2}{*}{ Tree savannas } & PAs & 411.7 & 183.9 & \multirow{2}{*}{0.081} & 10.07 & 3.29 & \multirow{2}{*}{0.681} \\
\hline & & UAs & 645.0 & 356.1 & & 10.94 & 5.56 & \\
\hline & \multirow{2}{*}{ Woodland savannas } & PAs & 468.8 & 159.6 & \multirow{2}{*}{0.322} & 13.35 & 7.45 & \multirow{2}{*}{0.206} \\
\hline & & UAs & 401.0 & 176.5 & & 9.99 & 4.12 & \\
\hline \multirow{10}{*}{ SS } & \multirow{2}{*}{ Gallery forests } & PAs & 703.3 & 172.2 & \multirow{2}{*}{0.942} & 81.63 & 48.15 & \multirow{2}{*}{$0.024^{*}$} \\
\hline & & UAs & 710.0 & 231.0 & & 38.22 & 12.93 & \\
\hline & \multirow{2}{*}{ Shrub savannas } & PAs & 931.8 & 190.2 & \multirow{2}{*}{$0.006^{*}$} & 7.35 & 1.81 & \multirow{2}{*}{0.236} \\
\hline & & UAs & 690.0 & 177.8 & & 6.39 & 1.89 & \\
\hline & \multirow{2}{*}{ Tree savannas } & PAs & 705.5 & 117.9 & \multirow{2}{*}{$0.000^{*}$} & 13.43 & 6.72 & \multirow{2}{*}{0.052} \\
\hline & & UAs & 440.0 & 185.2 & & 9.43 & 1.92 & \\
\hline & \multirow{2}{*}{ Woodland savannas } & PAs & 622.9 & 180.2 & \multirow{2}{*}{0.090} & 17.15 & 4.71 & \multirow{2}{*}{0.720} \\
\hline & & UAs & 496.2 & 193.6 & & 16.26 & 7.73 & \\
\hline & \multirow{2}{*}{ Woodlands } & PAs & 765.3 & 188.8 & \multirow{2}{*}{$0.001^{*}$} & 29.33 & 13.67 & \multirow{2}{*}{0.099} \\
\hline & & UAs & 528.0 & 116.0 & & 20.99 & 9.05 & \\
\hline
\end{tabular}

NS: north sudanian, SS: south sudanian, $\mathrm{N} \cdot \mathrm{ha}^{-1}$ : number of individual per hectare, and SE: standard error.

* Significant value.

in the woodlands were the exclusive species in PAs. The mean stem density increased significantly from UAs to the PAs in the shrub savannas $(P=0.006)$, tree savannas $(P=0.000)$, and woodlands $(P=0.001)$. However, the mean basal area did not show a significant difference between both land use types (Table 3). In both management regimes, the observed SCDs for all plant communities indicated a reverse J-shaped curve with the Weibull distribution $c$-value smaller than or close to 1 (Figure 3(b)). This is typical of a relatively stable multispecific population. The log-linear analysis (computed for each vegetation community) indicated a good adjustment of the observed distribution to the Weibull distribution (see Table 4).

3.2. Species Diversity and Similarity between Land Use Types. Among the diversity indices, Shannon's measure of evenness and Simpson's diversity index were not significantly different between land use types for all vegetation communities (Table 1). However, according to Hill's indices all vegetation communities were relatively diverse on the two sites (NS and SS) and did not show any significant differences between the PAs and the UAs. When comparing species similarity between vegetation communities in the NS (Table 2), similarity was fairly low between tree savannas from PAs and those from UAs $(33.3 \%$ and $28.8 \%$ for Jaccard's index and Morisita's index, resp.). The highest similarity (51.5\% and $58.9 \%$ for Jaccard's index and Morisita's index, resp.) was observed between the shrub savannas of the PAs and the UAs in both land use types.

In the south sudanian, Shannon's measure of evenness $(P=0.010)$ and Simpson's diversity index $(P=0.015)$ were significantly different for woodlands in both land use types (Table 1).

According to Hill's indice, all vegetation communities were relatively diverse. The comparison of the species richness between vegetation types revealed a low similarity between gallery forests from PAs and those from UAs $(27.5 \%$ and $37.5 \%$ for Jaccard's index and Morisita's index, resp.). 
TABLE 4: Results of log-linear analysis (in SAS Inc., 1999 [22]) applied to diameter class frequency.

\begin{tabular}{|c|c|c|c|c|c|c|c|c|}
\hline \multirow{3}{*}{ Sectors } & \multirow{3}{*}{ Vegetation communities } & \multicolumn{7}{|c|}{$\begin{array}{l}\text { The CATMOD procedure } \\
\text { Maximum likelihood analysis of variance }\end{array}$} \\
\hline & & \multicolumn{4}{|c|}{ Protected areas } & \multicolumn{3}{|c|}{ Unprotected areas } \\
\hline & & Source & $\mathrm{DF}$ & Chi square & $\operatorname{Pr}>$ ChiSq & DF & Chi square & $\operatorname{Pr}>$ ChiSq \\
\hline \multirow{12}{*}{ NS } & \multirow{4}{*}{ Gallery forests } & Class & 9 & 124.23 & $<0.0001$ & 9 & 157.98 & $<0.0001$ \\
\hline & & Distr. & 1 & 0.01 & 0.9364 & 1 & 0.02 & 0.8749 \\
\hline & & Class $*$ Distr. & 9 & 3.97 & $0.9134^{*}$ & 9 & 1.12 & $0.9991^{*}$ \\
\hline & & Class & 4 & 147.24 & $<0.0001$ & 4 & 174.12 & $<0.0001$ \\
\hline & \multirow[t]{3}{*}{ Shrub savannas } & Distr. & 1 & 0.00 & 0.9634 & 1 & 0.06 & 0.8053 \\
\hline & & Class $*$ Distr. & 4 & 0.41 & $0.9815^{*}$ & 4 & 0.55 & $0.9682^{*}$ \\
\hline & & Class & 9 & 141.34 & $<0.0001$ & 7 & 132.19 & $<0.0001$ \\
\hline & \multirow[t]{3}{*}{ Tree savannas } & Distr. & 1 & 0.01 & 0.9400 & 1 & 0.00 & 1.0000 \\
\hline & & Class $*$ Distr. & 7 & 0.47 & $0.9996^{*}$ & 5 & 1.15 & $0.9500^{*}$ \\
\hline & & Class & 9 & 136.22 & $<0.0001$ & 9 & 117.33 & $<0.0001$ \\
\hline & \multirow[t]{2}{*}{ Woodland savannas } & Distr. & 1 & 0.32 & 0.5714 & 1 & 0.00 & 1.0000 \\
\hline & & Class $*$ Distr. & 8 & 0.82 & $0.9992 *$ & 7 & 1.30 & $0.9885^{*}$ \\
\hline \multirow{15}{*}{ SS } & \multirow{4}{*}{ Gallery forests } & Class & 9 & 70.19 & $<0.0001$ & 9 & 97.12 & $<0.0001$ \\
\hline & & Distr. & 1 & 0.00 & 0.9509 & 1 & 0.13 & 0.7179 \\
\hline & & Class $*$ Distr. & 9 & 6.61 & $0.6774^{*}$ & 9 & 3.30 & $0.9514^{*}$ \\
\hline & & Class & 4 & 171.71 & $<0.0001$ & 4 & 155.18 & $<0.0001$ \\
\hline & \multirow[t]{3}{*}{ Shrub savannas } & Distr. & 1 & 0.17 & 0.6828 & 1 & 0.00 & 0.9866 \\
\hline & & Class $*$ Distr. & 4 & 0.62 & $0.9607^{*}$ & 4 & 0.03 & $0.9999^{*}$ \\
\hline & & Class & 8 & 224.44 & $<0.0001$ & 7 & 121.65 & $<0.0001$ \\
\hline & \multirow[t]{3}{*}{ Tree savannas } & Distr. & 1 & 0.02 & 0.8998 & 1 & 0.15 & 0.7012 \\
\hline & & Class $*$ Distr. & 7 & 1.50 & $0.9825^{*}$ & 6 & 1.82 & $0.9357^{*}$ \\
\hline & & Class & 9 & 142.41 & $<0.0001$ & 9 & 120.31 & $<0.0001$ \\
\hline & \multirow[t]{3}{*}{ Woodland savannas } & Distr. & 1 & 0.00 & 1.0000 & 1 & 0.32 & 0.5714 \\
\hline & & Class $*$ Distr. & 8 & 0.58 & $0.9998^{*}$ & 8 & 1.02 & $0.9981^{*}$ \\
\hline & & Class & 9 & 150.30 & $<0.0001$ & 9 & 131.22 & $<0.0001$ \\
\hline & \multirow[t]{2}{*}{ Woodlands } & Distr. & 1 & 0.17 & 0.6758 & 1 & 0.04 & 0.8378 \\
\hline & & Class $*$ Distr. & 9 & 0.94 & $0.9996^{*}$ & 9 & 2.07 & $0.9903^{*}$ \\
\hline
\end{tabular}

An interaction "Class $*$ Distr." significant $(P>0.05)$ shows that the conformation between observed structure and Weibull Distribution is accepted.

*See values.

The highest similarity $(54.1 \%$ and $56.5 \%$ for Jaccard's index and Morisita's index, resp.) was observed between the shrub savannas in both land use types.

\section{Discussion}

The overall species richness found in this study is higher than that of native woody species reported in the country. Fontès and Guinko [11] have reported that woody flora of the country comprises 188 species. Concerning the species richness, the analysis provides nuanced results. The protection effect was evidenced by a significantly higher number of species in PAs for shrub savannas, woodland savannas, and woodlands in the south sudanian sector and tree savannas in both sectors. However, the role of protected areas in the conservation of plant diversity in savannah regions is appreciated in various ways. Although some studies demonstrated loss of plant diversity due to human pressure in exploited lands or, conversely, floristic preservation inside protected areas [23], other studies showed that phytodiversity does not differ in both land use types, and it is even higher outside protected areas [24-27]. This might be an indication that protection measures in semiarid areas ensure the conservation of the existing diversity but not always adequate for enhancing lands diversity. This idea is supported by Devineau [28] who reported an increasing recruitment of plants in fallows, favoured by moderate pasture. It is well established that the traditional long fallow system combined with agroforestry practices have a positive effect on land conservation [8]. Consequently, species richness is sometimes even higher in these areas than in the protected areas $[25,29]$. The most common families were Rubiaceae, Combretaceae, Leguminosae-Caesalpinioideae, and Leguminosae-Mimosoideae; this is a typical taxonomic pattern of savanna-woodland mosaics flora in Sudano-Sahelian Africa $[1,11]$. 
According to Shannon's and Simpson's diversity indices, woody plant populations of woodland in PAs were more diversified than in the UAs. This is most likely related to the relatively large numbers of abundant species in woodlands plots (e.g., Cola cordifolia, Erythrophleum suaveolens, Lonchocarpus cyanescens, and Mimusops kummel). Shannon's diversity index is usually found to fall between 1.5 and 3.5 and is rarely above 5.0 [15]. The values from our results are in the expected range. The similarity in species composition and abundance between the land use types was generally low, except for the shrub savannas. This plant community exhibited $51.5 \%$ and $58.9 \%$ in the north and $54.1 \%$ and $56.5 \%$ in the south sudanian sector for species composition and abundance similarity, respectively. The low values of similarity indices reflect differences in habitat and topography conditions.

Concerning the structural parameters of woody populations, a gradual increase was found for the mean stems density from UAs to the PAs only in the south Sudanian sector for shrub savannas, tree savannas, woodland savannas, and woodlands. This difference in individuals' density between both land use types might be due to the variable disturbance density $[1,27]$. Generally, the survival and growth of tree species in semiarid savanna ecosystems are favoured by good moisture and edaphic conditions [30,31] but strongly disturbed by direct and indirect human activities $[32,33]$. The reverse "J" shape of SCDs for all plant communities in both zones, irrespective of land use types, is an indication of good regeneration of populations [34,35]. A large number of individuals with $\mathrm{dbh} \leq 5 \mathrm{~cm}$ were found in all land use types, indicating a potential renewal of the population for all plant communities [35-37].

The reverse "J" structure observed for each vegetation community may be explained by a kind of compensation between the species in the different SCDs, so that the species with slow growth are compensated by those with rapid growth. This is due to the importance of the phenomena of competition (for nutrients) between trees in the savannas [38] which make that some species are more favored than others.

\section{Conclusion}

Our results provide information that globally species diversity and richness are not significantly better in protected areas than in unprotected ones. However, certain plant communities are favoured by protection. This is the case of tree savannas in north and south sudanian sectors. Although they are currently disturbed, open access lands are areas of active plant materials flows (mainly by pasture and human direct activities) that favours diversification. The role of PAs, in terms of plant community conservation, is unquestionable as they ensure safety recruitment and survival of new individuals, which is primordial for population rejuvenation and consequently the plant diversity conservation. This suggests that, even if in certain cases, the PAs do not exhibit a higher phytodiversity, they play a key role in terms of warranty for the conservation of the existing diversity.

\section{Acknowledgments}

This paper was achieved within the framework of the BIOTAWest Africa Program (Project: 01LC0617D1W11) funded by the German Federal Ministry for Education and Research (BMBF). The authors are very grateful to their field assistants who helped them in data collection. Many thanks to Abel Kadéba for mapping the study site. They are also grateful to the anonymous reviewers whose pertinent comments considerably improved the quality of their paper.

\section{References}

[1] F. Bognounou, A. Thiombiano, P. Savadogo, J. I. Boussim, P. C. Odén, and S. Guinko, "Woody vegetation structure and composition at four sites along latitudinal gradient in Western Burkina Faso," Bois et Forêts des Tropiques, vol. 300, no. 2, pp. 29-44, 2009.

[2] M. M. Inoussa, A. Mahamane, C. Nbow, M. Saadou, and B. Yvonne, "Dynamiques spatio-temporelle des forêts claires dans le Parc national du W du Niger (Afrique de l'Ouest)," Sécheresse, vol. 22, pp. 108-116, 2011.

[3] B. S. Bouko, B. Sinsin, and G. B. Soulé, "Effets de la dynamique d'occupation du sol sur la structure et la diversité floristique des forêts claires et savanes au Bénin," Tropicultura, vol. 25, no. 4, pp. 221-227, 2007.

[4] S. L. Ariori and P. Ozer, "Évolution des ressources forestières en Afrique de l'Ouest soudano-sahélienne au cours des cinquante dernières années," International Journal of Tropical Geology Geography and Ecology, no. 29, pp. 61-68, 2005.

[5] H. Sawadogo, P. N. Zombré, L. Bock, and D. Lacroix, "Évolution de l'occupation du sol de Ziga dans le Yatenga (Burkina Faso) à partir de photos aériennes," Revue de Télédétection, vol. 8, pp. 59-73, 2008.

[6] H. Diallo, I. Bamba, Y. Sadaiou et al., "Effets combinés du climat et des pressions anthropiques sur la dynamique évolutive de la végétation d'une zone protégée du Mali (Réserve de Fina, Boucle du Baoulé)," Sécheresse, vol. 22, no. 2, pp. 97-107, 2011.

[7] S. Caillault, D. Delahaye, and A. Ballouche, "Des cultures temporaires face à la forêt classée, exemple des paysages à l'ouest du Burkina Faso," 13p, 2010, http://www.projetsdepaysage.fr .

[8] R. J. Buresh and P. J. M. Cooper, "The science and practice of short-term improved fallows: symposium synthesis and recommendations," Agroforestry Systems, vol. 47, no. 1-3, pp. 345-356, 1999.

[9] D. Zida, Impact of forest management regimes on ligneous regeneration in the Sudanian savanna of Burkina Faso [Ph.D. thesis], Swedish University of Agricultural Sciences, Umeå, Sweden, 2007.

[10] P. Savadogo, Dynamics of Sudanian savanna-woodland ecosystem in response to disturbances [Ph.D. thesis], Swedish University of Agricultural Sciences, Umeå, Sweden, 2007.

[11] J. Fontès and S. Guinko, "Carte de la végétation et de l'occupation du sol (Burkina Faso)," Notice Explicative, Laboratoire d'Écologie Terrestre, Institut de la Carte Internationale de la Végétation. CNRS, Université de Toulouse III, (France)/Institut du Développement Rural, Faculté des Sciences et Techniques, Université de Ouagadougou, Ouagadougou, Burkina Faso, 1995.

[12] F. Bognounou, M. Tigabu, P. Savadogo et al., "Regeneration of five Combretaceae species along a latitudinal gradient 
in Sahelo-Sudanian zone of Burkina Faso," Annals of Forest Science, vol. 67, no. 3, 2010.

[13] U. Belemsobgo, P. Kafando, B. A. Adouabou et al., "Network of protected areas," in Biodiversity Atlas of West Africa, A. Thiombiano and D. Kampmann, Eds., vol. 2, pp. 354-363, Ouagadougou, Burkina Faso, 2010.

[14] A. Aubreville, "Accord à Yangambi sur la nomenclature des types africains de végétation," Bois et Forêts des Tropiques, no. 51, pp. 23-27, 1957.

[15] A. E. Magurran, Measuring Biological Diversity, Blackwell Publishing, Malden, Mass, USA, 2004.

[16] N. L. Johnson and S. Kotz, Distributions in Statistics: Continuous Univariate Distributions, John Wiley and Sons, New York, NY, USA, 1970.

[17] S. J. Zarnock and T. R. Dell, "An evaluation of percentile and maximum likelihood estimators of Weibull parameters," Forest Sciences, vol. 31, pp. 260-268, 1985.

[18] K. A. Ryniker, J. K. Bush, and O. W. Van Auken, "Structure of Quercus gambelii communities in the Lincoln National Forest, New Mexico, USA," Forest Ecology and Management, vol. 233, no. 1, pp. 69-77, 2006.

[19] C. G. Lorimer and A. G. Krug, "Diameter distributions in even-aged stands of shade-tolerant and midtolerant tree species," American Midland Naturalist, vol. 109, no. 2, pp. 331345, 1983.

[20] P. J. Baker, S. Bunyavejchewin, C. D. Oliver, and P. S. Ashton, "Disturbance history and historical stand dynamics of a seasonal tropical forest in western Thailand," Ecological Monographs, vol. 75, no. 3, pp. 317-343, 2005.

[21] H. Caswell, Matrix Population Models: Construction Analysis and Interpretation, Sinauer Associates, 2nd edition, 2001.

[22] SAS Inc., SAS/STAT User's Guide, SAS Institute, Cary, NC, USA, 1999.

[23] S. Guinko, P. Ouoba, and J. Millogo-Rasolomdimby, "L'apport de l'inventaire des aires classes et protégées dans la connaissance de la diversité végétale du Burkina Faso," Ber Sonderforschungsbereichs, vol. 268, no. 14, pp. 257-271, 2000.

[24] C. M. Shackleton, "Comparison of plant diversity in protected and communal lands in the Bushbuckridge lowveld savanna, South Africa," Biological Conservation, vol. 94, no. 3, pp. 273 285,2000

[25] K. Hahn-Hadjali, M. Schmidt, and A. Thiombiano, "Phytodiversity dynamics in pastured and protected West African savannas," in Taxonomy and Ecology of African Plants, Their Conservation and Sustainable Use, S. A. Ghazanfar and H. J. Beentje, Eds., pp. 351-359, Royal Botanic Gardens, Kew, 2006.

[26] T. A. Gardner, T. Caro, E. B. Fitzherbert, T. Banda, and P. Lalbhai, "Conservation value of multiple-use areas in East Africa," Conservation Biology, vol. 21, no. 6, pp. 1516-1525, 2007.

[27] B. M. I. Nacoulma, K. Schumann, S. Traoré et al., "Impacts of land-use on West African savanna vegetation: a comparison between protected and communal area in Burkina Faso," Biodiversity and Conservation, vol. 20, no. 14, pp. 3341-3362, 2011.

[28] J. L. Devineau, "Rôle du bétail dans le cycle culture-jachère en région soudanienne : la dissémination d'espèces végétales colonisatrices d'espaces ouverts (Bondoukuy, sud-ouest du Burkina Faso)," Revue Ecologique Terre et Vie, vol. 54, pp. 97$121,1999$.

[29] J. L. Devineau, A. Fournier, and S. Nignan, "'Ordinary biodiversity' in western Burkina Faso (West Africa): what vegetation do the state forests conserve?" Biodiversity and Conservation, vol. 18, no. 8, pp. 2075-2099, 2009.
[30] R. Bellfontaine, A. Gaston, and Y. Petrucci, Management of Natural Forest of Dry Tropical Zones, vol. 32 of Conservation guide, FAO, Rome, Italy, 2000.

[31] J. J. Wiens and M. J. Donoghue, "Historical biogeography, ecology and species richness," Trends in Ecology and Evolution, vol. 19, no. 12, pp. 639-644, 2004.

[32] A. Ouédraogo, A. Thiombiano, K. Hahn-Adjali, and S. Guinko, "Diagnostic de l'état de dégradation des peuplements de quatre espèces ligneuses en zone soudanienne du Burkina Faso," Sécheresse, vol. 17, no. 4, pp. 485-491, 2006.

[33] A. Ouédraogo and A. Thiombiano, "Regeneration pattern of four threatened tree species in Sudanian savannas of Burkina Faso," Agroforestry Systems, vol. 861, pp. 35-48, 2012.

[34] F. E. Fongnzossie, N. Tsabang, B. A. Nkongmeneck et al., "Les peuplements d'arbres du Sanctuaire à gorilles de Mengamé au sud Cameroun," Tropical Conservation Science, vol. 1, no. 3, pp. 204-221, 2008.

[35] W. Bonou, R. Glèlè Kakaï, A. E. Assogbadjo, H. N. Fonton, and B. Sinsin, "Characterisation of Afzelia Africana Sm. habitat in the Lama forest reserve of Benin," Forest Ecology and Management, vol. 258, no. 7, pp. 1084-1092, 2009.

[36] H. Zegeye, D. Teketay, and E. Kelbessa, "Diversity, regeneration status and socio-economic importance of the vegetation in the islands of Lake Ziway, south-central Ethiopia," Flora, vol. 201, no. 6, pp. 483-498, 2006.

[37] A. Gnoumou, F. Bognounou, K. Hahn, and A. Thiombiano, "A comparison of Guibourtia copaliffera Benn. Stands in South West Burkina Faso-community structure and regeneration," Journal of Forestry Research, vol. 22, no. 4, pp. 551-559, 2011.

[38] J. L. Devineau, "Évolution saisonnière et taux d'accroissement des surfaces terrières des ligneux dans quelques peuplements savanicoles soudaniennes de l'ouest burkinabé," Ecologie, vol. 28, no. 3, pp. 217-232, 1997. 

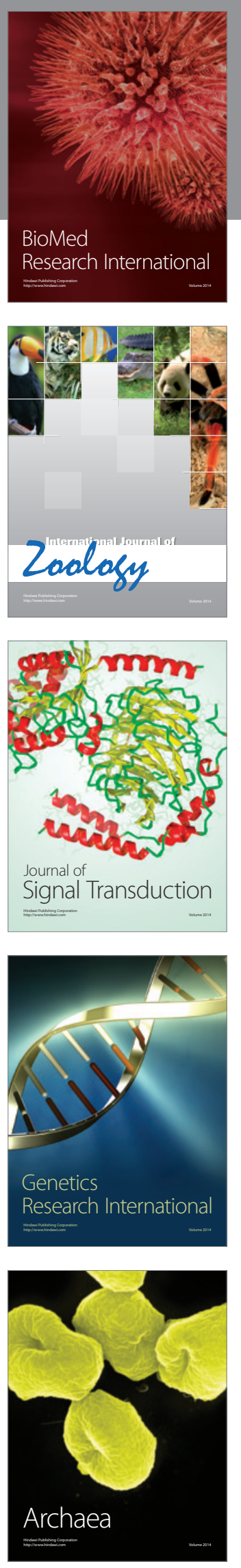
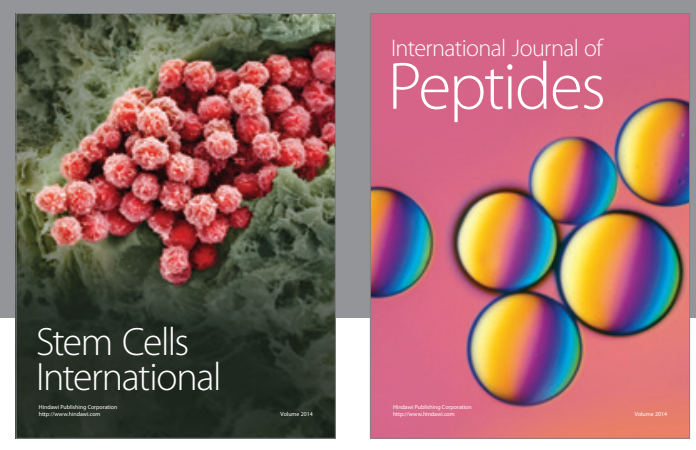

Submit your manuscripts at

http://www.hindawi.com
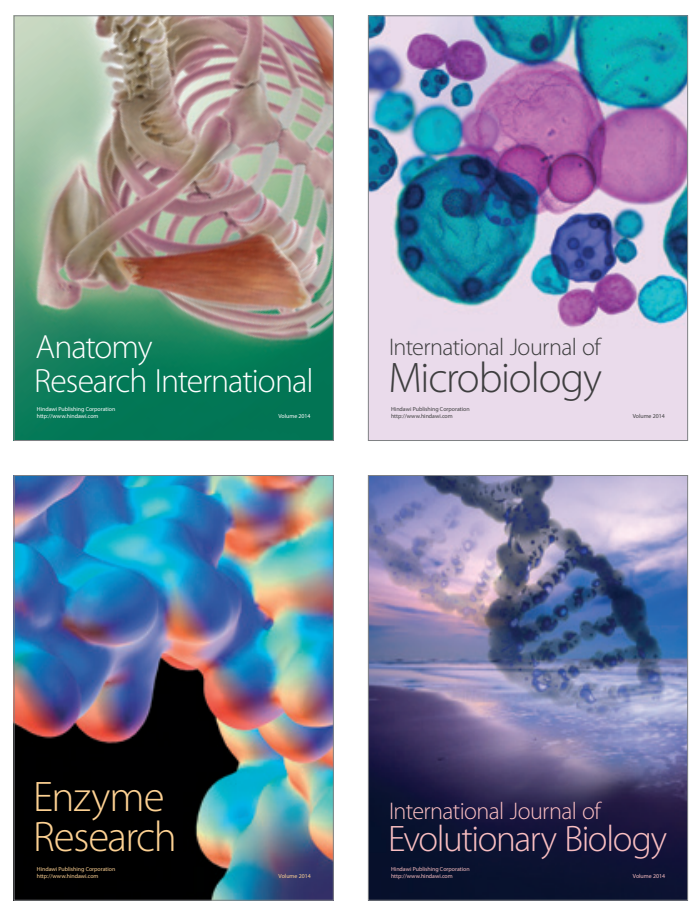
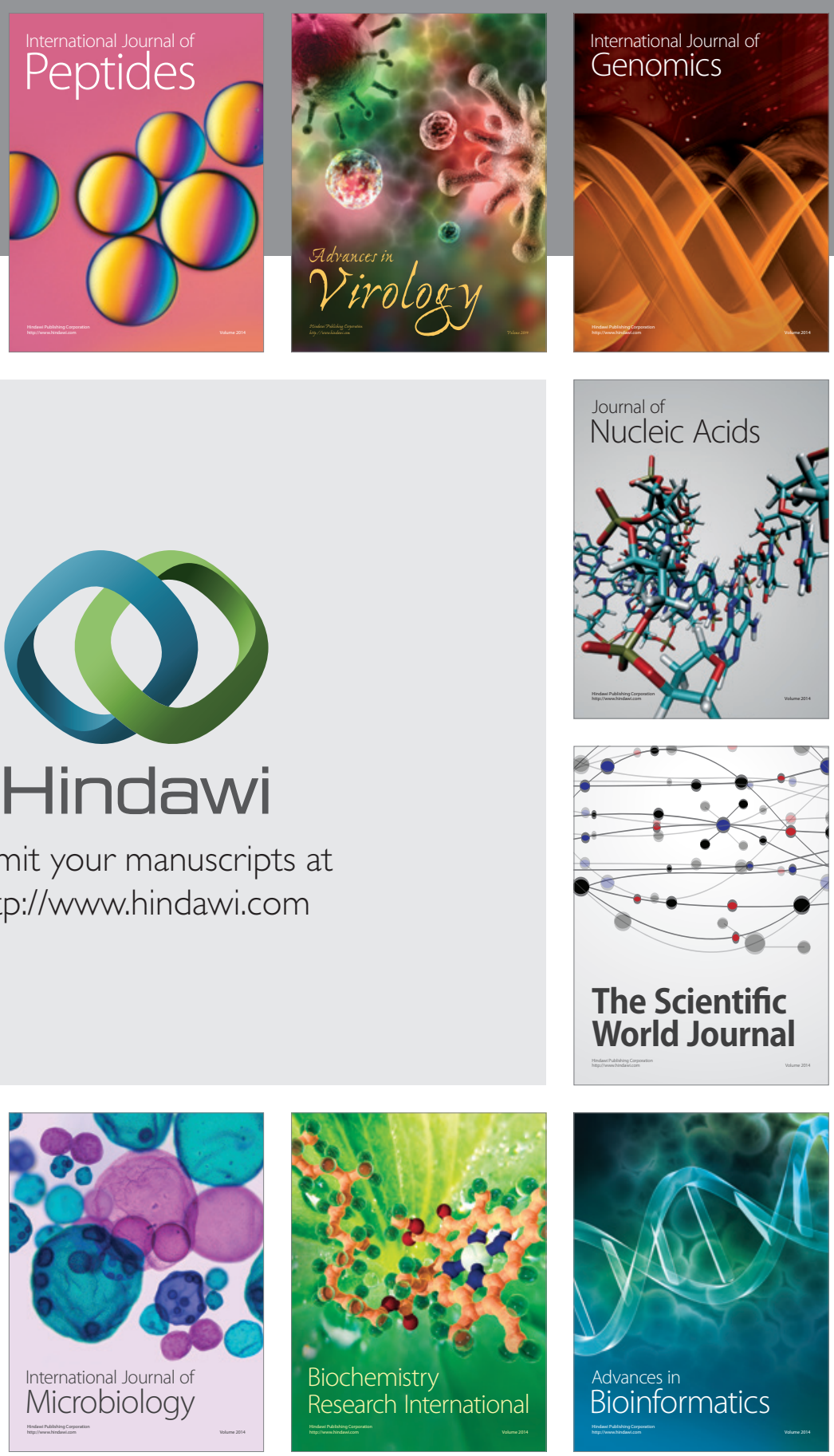

The Scientific World Journal
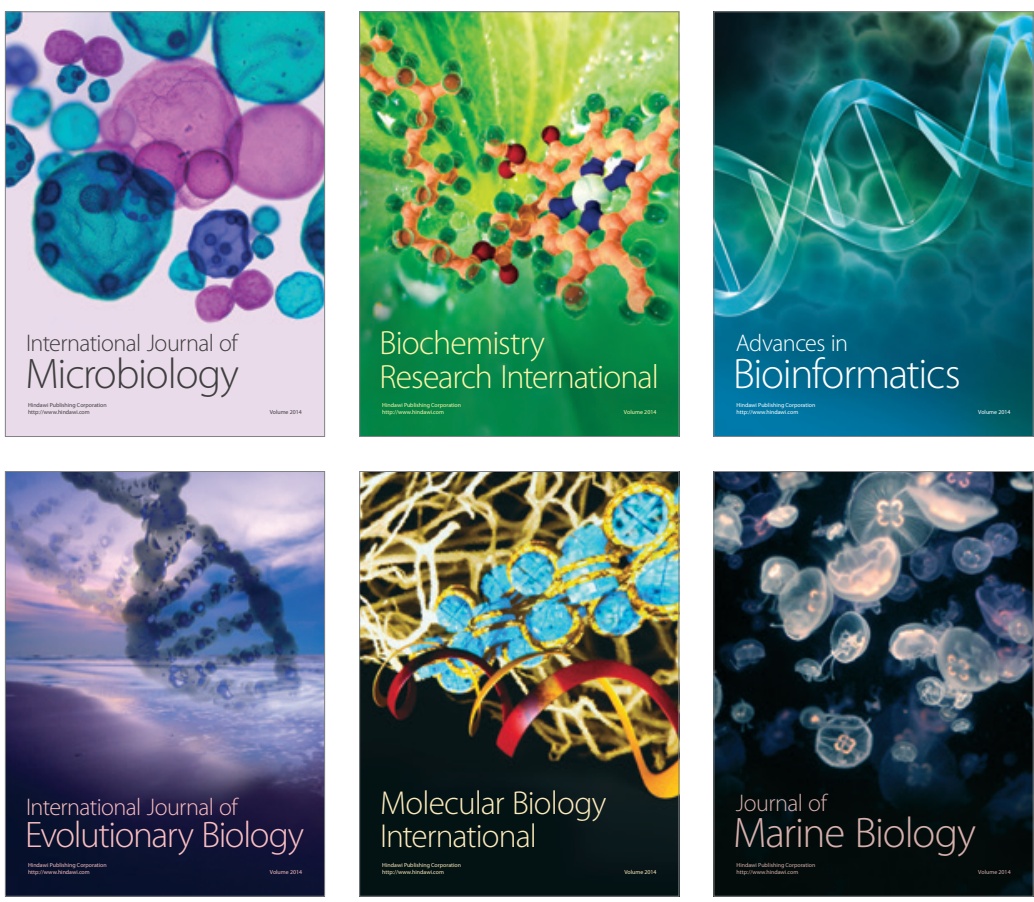